\title{
Current Trends in Medicinal Chemistry
}

Editorial Article

\section{Setting up Pioneering Research in Medicinal Plant: A Multidisciplinary Approach}

\section{Farideh Javid}

Department of Pharmacy, School of Applied Sciences, University of Huddersfield, UK

"Corresponding author: Farideh Javid, School of Applied Sciences, University of Huddersfield, UK Tel: 01484 472543; Email: fajavid@hud.ac.uk

Citation: Farideh Javid (2017) Setting up Pioneering Research in Medicinal Plant: A Multidisciplinary Approach. Arch Nat Med Chem 2017-J102

Received Date: 16 January, 2017; Accepted Date: 1 February, 2017; Published Date: 7 February, 2017

We live in an era which necessitates integration between different branches of sciences to tackle human health problems. This is highlighted with current major problems associated with the fast growing incidence of diseases such as cancers, Alzeheimers/Demnetia, not forgetting the global problem of resistance to antibiotics. Thus multidisciplinary teams of scientists including physicians, pharmacologists, biologists and chemists should work alongside the pharmaceutical industry to develop novel treatments or approaches in treating human diseases. With an increase in drug resistance and side effects associated with current medications more and more scientists are convinced that natural plants should be the focus of our effort in designing and identifying novel treatments. It is therefore not surprising that the World Health Organization (WHO) has published new guidelines on the development of medicinal plants/traditional medicine [1]. This has allowed scientists to focus on standardizing the active ingredients extracted from the plants and has encouraged pharmacologists to investigate their mechanism of actions in biological models. There is growing evidence that medicinal plants are a very good source of antioxidants and they can induce anti-microbial, anti-cancer, anti-diabetes effects as well as neuro-and immune-protective, antiinflammatory and preventive effects [2-9]. Attention to medicinal plants has also increased the impact of journals publishing data on the effects of plants/extracts in a variety of pharmacological and biological models.

In this journal attempts are made to ensure the publication of high standard peer-reviewed articles which would be useful for a broad spectrum guidance in healthcare, academia and industry. Indeed, discovery of the medicinal properties of plants is the main focus of this journal which would hopefully encourage further collaboration with other colleagues in other areas.

\section{References}

1. World Health Organization (WHO) Traditional Medicine Strategy : 2014-2023. (2013)

2. Rafieian-Kopaie M, Baradaran A (2013) Plants antioxidants: From laboratory to clinic. J Nephropathol 2: 152-153.

3. Zhou J, Li PT (1992) Research of antibacterial mechanism of Litsea cubeba oil in Staphylococcus aureus. Bulletin of Human Medicinal University 17: 329-332.

4. Damjanović-Vratnica B, Đakov T, Šuković D, Damjanović J (2011) Antimicrobial effect of essential oil isolated from Eucalyptus globulus Labill. from Montenegro. Czech J Food Sci. 29: 277-284.

5. Ho CL, Ou JP, Liu YC, Hung CP, Tsai MC, et al. (2010) Compositions and in vitro anticancer activities of the leaf and fruit oils of Litseacubebafrom Taiwan. Nat Prod Commun 5: 617-620.

6. Kazemi S, Asgary S, Moshtaghian J, Rafieian M, Adelnia A, et al. (2010) Liver-protective effects of hydroalcoholic extract of allium hirtifolium boiss. In rats with alloxan - induced diabetes mellitus. ARYA Atheroscler 6: 11-15.

7. Shirzad H, Shahrani M, Rafieian-Kopaei M (2009) Comparison of morphine and tramadol effects on phagocytic activity of mice peritoneal phagocytes in vivo. Int Immunopharmacol 9: 968-970.

8. Choi EM, Hwang JK (2004) Effects of methanolic extract and fractions from Litseacubebabark on the production of inflammatory mediators in RAW264.7 cells. Fitoterapia 75: 141-148.

9. Heidarian E, Kopaei MR, Ashrafi K (2013) The effect of hydroalcoholic extract of Allium latifolium on the liver phosphatidate phosphatase and serum lipid profile in hyperlipidemic rats. J Babol Univ Med Sci 15: $37-46$. 